Article

\title{
A Monitoring and Evaluation Sustainability Framework for Road Freight Transporters in South Africa
}

\author{
Chumasande Lalendle ${ }^{1}$, Leila Goedhals-Gerber ${ }^{1, * \mathbb{D}}$ and Joubert van Eeden ${ }^{2}$ (D) \\ 1 Department of Logistics, Stellenbosch University, Stellenbosch 7602, South Africa; lalendle@sun.ac.za \\ 2 Department of Industrial Engineering, Stellenbosch University, Stellenbosch 7602, South Africa; \\ jveeden@sun.ac.za \\ * Correspondence: leila@sun.ac.za; Tel.: +27-21-8082252
}

Citation: Lalendle, C.;

Goedhals-Gerber, L.; van Eeden, J. A

Monitoring and Evaluation

Sustainability Framework for Road Freight Transporters in South Africa. Sustainability 2021, 13, 7558. https:// doi.org/10.3390/su13147558

Academic Editors: Jozef Gašparík and Davor Dujak

Received: 31 May 2021

Accepted: 30 June 2021

Published: 6 July 2021

Publisher's Note: MDPI stays neutral with regard to jurisdictional claims in published maps and institutional affiliations.

Copyright: (c) 2021 by the authors. Licensee MDPI, Basel, Switzerland. This article is an open access article distributed under the terms and conditions of the Creative Commons Attribution (CC BY) license (https:// creativecommons.org/licenses/by/ $4.0 /)$.

\begin{abstract}
Growing freight volumes contribute to negative impacts on the environment and social aspects. In South Africa, an overreliance on road freight transportation systems (RFTS) over alternative modes of transport puts a further strain on the RFTS. Hence, there was a need to develop a monitoring and evaluation (M\&E) sustainability assessment framework. The framework development was guided by a multistage process: Firstly, Identifying Constructs and Variables relevant to the study. Secondly, Developing the M\&E Framework included defining sustainability in the transport sector, using themes emerging from an operational definition and South Africa's vision for transport sustainability. Thirdly, Soliciting inputs and measures were utilized in developing the framework. Finally, the Validity and Reliability of the framework was tested. This study developed an M\&E framework, which affords organizations a balanced mechanism for tracking inputs towards transport system sustainability, facilitating infrastructure decision-making and driving RFTS sustainability. As road freight transport contributes the most towards environmental unsustainability of the sector, this mode also holds the greatest opportunity to reduce its impact. The M\&E framework will enable role-players to plan, execute, and monitor their RFTS interventions in a balanced way.
\end{abstract}

Keywords: framework; monitoring and evaluation; road freight transport; sustainability; South Africa

\section{Introduction}

Logistics companies upgrade and replace their transport infrastructure on a cyclical basis. These medium- to long-term infrastructure decisions are often driven by financial measures alone, thus not incorporating the dimensions of environmental and social responsibility. These decisions should rather be governed by a balanced view based on a comprehensive definition of sustainability. This paper strives to create a monitoring and evaluation (M\&E) framework to resolve this gap.

Prior to 1930, regulatory control in the South African transport sector was not evident, but with growing competition threatening the rail industry, recommendations for stricter control of road transport inspired the Motor Carrier Transportation Act 39 of 1930. This piece of legislation required the use of a permit for 'hire or reward' road transportation in South Africa. In 1977, the updated Road Transportation Act 14 of 1977 was passed, with significant moves away from the 1930 Act, allowing for more goods to be transported by road [1].

In 1984, South Africa began to engage in comprehensive traffic observations [2]. Substantial volumes of freight moved from rail to road in 1988, as a result of the deregulation of road freight in South Africa. Since then, road freight traffic has increased and continues to increase. The statistics captured by the Transport Statistics Bulletin [3] indicated an average growth rate of 3\% for all motorized vehicles and 2.05\% for trucks in South Africa for the years 2010 to 2015. They further reported that there were 366479 registered trucks on South Africa's roads in 2015. 
Heavy Goods Vehicles (HGV) make up 34\% of the traffic on the N3 [4], a national road $600 \mathrm{~km}$ long that connects South Africa's largest city in Gauteng to the closest port in South Africa, which is Durban (refer to Figure 1).

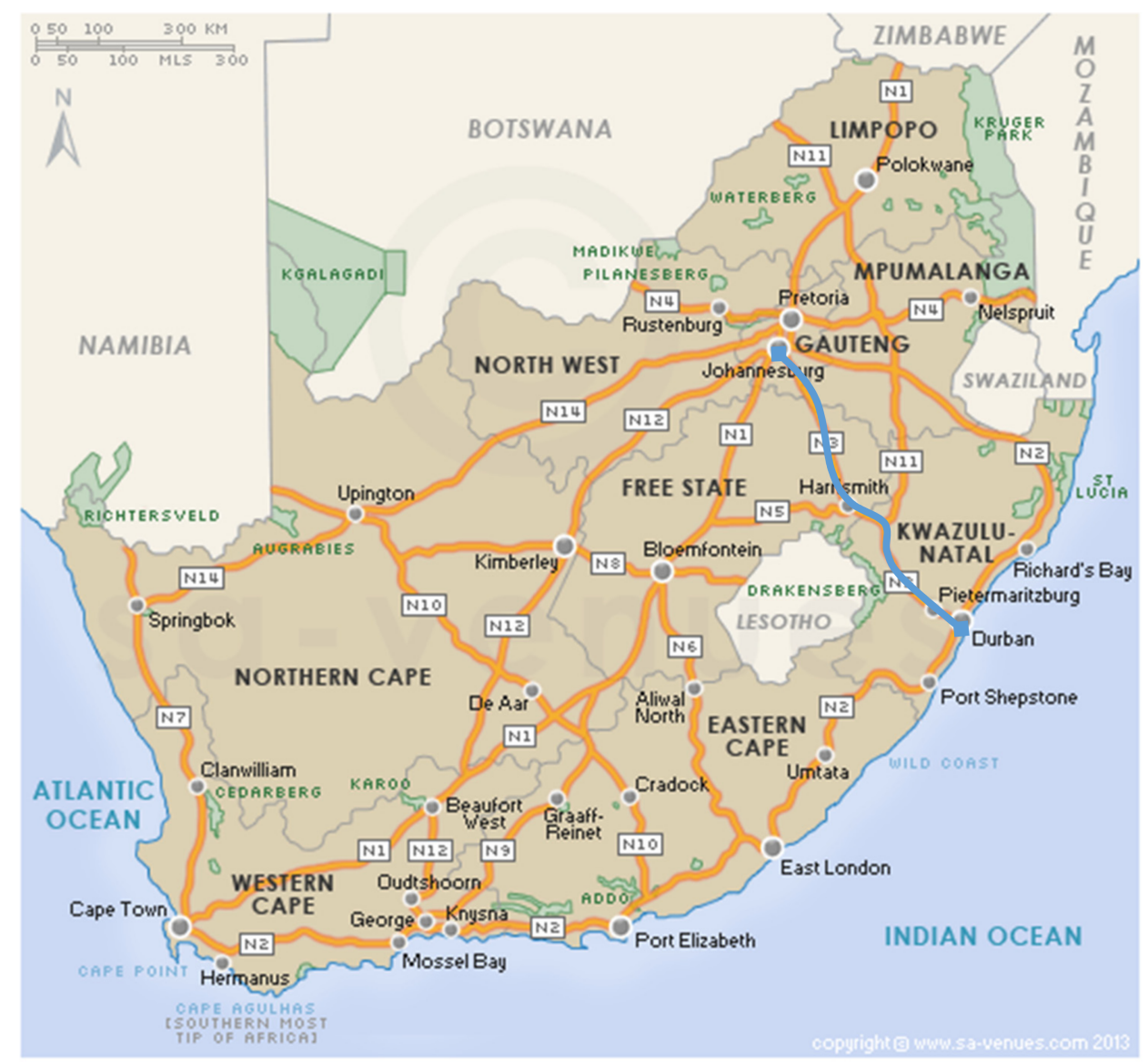

Figure 1. Map indicating the N3 road in South Africa connecting Gauteng and Durban [5].

The increased traffic from HGVs has also come with many negative externalities, such as rapidly deteriorating road infrastructure, high crash levels, congestion, and increased pollutant emissions [6]. One-third of the total energy Greenhouse Gases (GHG) emission contributions in South Africa are derived from the transport sector [7], and road transport is the key contributor to the total transport-related $\mathrm{CO}_{2}$ emissions in South Africa. Figure 2 shows that the road subsector accounts for $91.2 \%$ of the $10.8 \%$ of total GHG emitted by the transport sector, with rail transport emitting only $1.07 \%$ [8].

Managing the causes and effects of global warming is a global priority. Due to the high negative externalities that road transport contributes, road transport is the focus of the South African government's Green Transport strategy 2018-2050 [4]. Various literature sources indicated that road transport contributes the most to negative externalities in the transport sector. A study by Andersson and Holmberg [9] examined the impacts of freight transport in the Czech Republic referring to road transport as the greatest cause of pollution and overwhelmingly dominant mode of transport. A draft roads policy study [8] adds that in the South African case, as the majority of all freight is moved by road, the freight volumes contribute to air pollution, traffic congestion, and poor road safety, further exasperating the significant backlog in road maintenance. In a study by Demir et al. [10] road transport when measured against the other modes of transport (air, rail, and sea) accumulated the highest negative externality impact out of seven categories, and thus, can be seen as the mode that offers the highest reduction opportunities. 


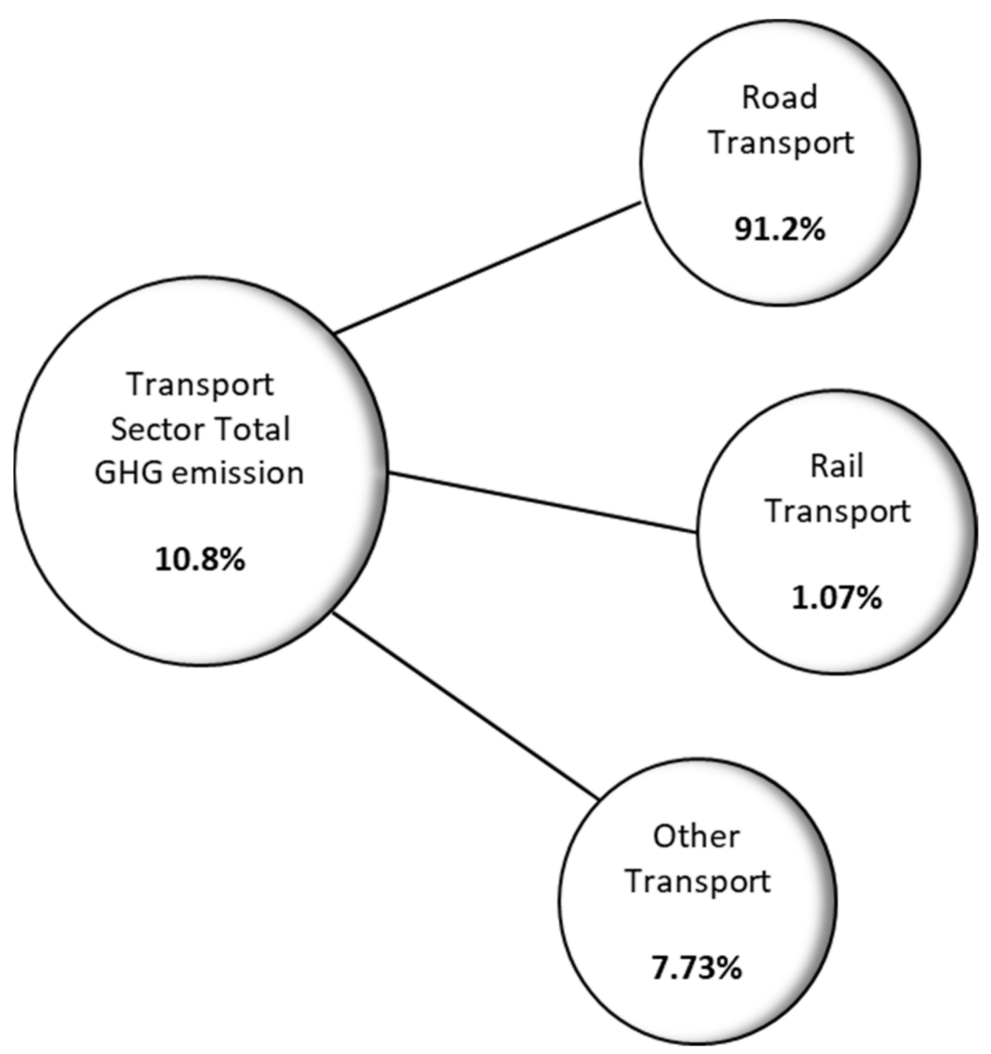

Figure 2. Emissions breakdown of the transport sector (compiled from [7]).

Emissions output is a global challenge; South Africa in particular, as a water-scarce country, faces risks from the severe effects of climate change. Drought and variability of rainfall linked to climate change could have devastating consequences for this developing country. A hindrance to the country's move toward a low carbon economy is its heavy reliance on coal as the dominant energy source [4]. The use of technology that promotes cleaner and efficient road freight transport needs to be developed in the freight industry together with regulatory action that facilitates a shift from road to rail to reduce the climate change risk that the country is susceptible to.

Another cause for concern is safety and the deterioration of road infrastructure. The high volume and weight that vehicles carry on the roads in South Africa accelerates the deterioration rates of national roads. All roads are built with an expected lifespan. Many of the roads in South Africa reach the end of their life prematurely due to the traffic load and harsh weather conditions. Moreover, $30 \%$ of the infrastructure condition is rated poor or very poor, while $78 \%$ of the national road network is thought to have exceeded its intended life design [4].

The Transport Statistics Bulletin of 2015 reported a year-by-year increase in the number of HGV from 2008-2015 [3]. No studies indicate that this trend has changed. Furthermore, the South African Government is in a backlog with road maintenance [11], and continuing with the status quo is not sustainable. The social, environmental, and economic sustainability of Road Freight Transport Systems (RFTS) are areas which this study focused on. In South Africa, there is a lack of academic material that provides tools for RFTS to assess their sustainability. Moreover, RFTS need to be developed sustainably, as their operations simultaneously produce negative externalities and the demand for their services have been growing since the deregulation of road transport and continues to grow. Therefore, it is imperative that industry understands their impact and has a tool to monitor and evaluate the balance of their sustainability initiatives. 


\section{Literature}

\subsection{Freight Transport and Road Freight Transport Systems (RFTS)}

Freight transport is a key contributor to local and regional economies [12], playing an essential role in connecting spatially separated places of supply and demand [13]. Its operations are predominately known to be made by sea, rail, air, road, or a combination thereof, between pickup station, ports, cities, and over long distances [14]. With an increasingly globalized world, freight transport enables supply chains, a vital success factor for economic prosperity [15].

Global freight volumes continue to rise, among the primary causes of this phenomenon is the advancement of megatrends such as digitalization, globalization, population growth, demographic changes, and rapid industrialization [16]. In light of the restrictions imposed by governments on social and economic daily life due to the destructive spread of the coronavirus (COVID-19), a shift in consumption behaviors of people occurred. It resulted in panic buying of households as well as a spike in the use of e-commerce for home deliveries [17], increasing the demand for supplies and road freight transport volumes during the pandemic [18,19].

Cranic [20] already described global traffic around cities as worsening in 2004. Road freight is carried by vehicles on the same roads as passenger vehicles contributing substantially towards congestion and an environmental hazard. This has caught the attention of various stakeholders (policy makers, operators, researchers, and NGOs) to find sustainable options for road freight transport operations. Road freight in South Africa is the largest sub-sector within the transport sector, accounting for more than $70 \%$ of the freight payload and $90 \%$ of the total road transport revenue earned, with the remainder proportioned to passenger income [21]. This highlights road freight in South Africa as the ideal subsector to monitor and evaluate its operations for sustainable development with the growth of traffic.

Road freight operations can be seen to take place within a complex system. A system consists of interacting elements working together for a common purpose [22]. For this article, RFTS should be understood as complex systems in which road freight transporters operate in; having common elements such as drivers, freight vehicles, and the built environment being roads. Although there are common elements of RFTS, these entities are also heterogeneous when it comes to the finer details of their operations. A study by Centobelli et al. [23] that provided a conceptual framework on the adoption of green initiatives by freight transport and logistics companies found that the companies in these industries do not operate in a homogeneous manner when taking decisions on sustainability initiatives. Hence, some customization of the framework provided in the article is recommended to better service the unique nature of the different companies. Each unique road freight system is managed or run by an organization/enterprise or government, which moves goods/cargo from a point of origin to a destination point through a mode of transport that uses road infrastructure. This article includes light freight vehicle delivery types such as vans and small trucks and heavy goods vehicle delivery types including flat bed, step deck, reefer, dump trailer, and tanker trucks.

\subsection{Monitoring $\mathcal{E}$ Evaluation}

The European Commission [24] contributed significantly to the development of knowledge, expertise, and incorporation of sustainable urban logistics concepts. They advise that monitoring and evaluation need to be built into projects in order to keep track of the progress of the process and implementation of initiatives or measures.

Monitoring and evaluation is a function of project and systems management that allows for transparency of changes made during the implementation process of a project. Monitoring is the ongoing activity of observing and recording outputs/results. This task is predominately tracked by management at a functional level, such as supervisors and line managers. Monitoring takes place over short periods and focuses on collecting data at specific pointers of daily activities; to provide early indicators of the degree of progress, change, development, or the lack thereof to stakeholders [25]. The process of monitoring 
can be seen as a function that supports evaluation. It enhances and emphasizes the quality of the assessment. Although the two are complementary, monitoring and evaluation seek to ask different questions and hence are considered separately [26].

Evaluation, however, is a periodic activity performed by managers to critically assess the outcomes of the impact of a project or system against the planned objectives. The process of evaluation requires clear understanding of the outcomes to determine the implications, effectiveness, and success of the project. In summary, monitoring and evaluation is the basic tool used to handle complex projects and systems [27] and goes beyond the prominence of inputs and outputs, but examines the results and impact of the initialized project or initiatives [28].

\section{Materials and Methods}

The objective of this paper was to develop an M\&E framework that will assess the sustainability of road freight transport systems operated by road freight transporters in South Africa. In order to assist organizations in assessing their RFTS with an assessment tool (M\&E framework) to track their current sustainability status, planned interventions, progress, and decline of sustainability. The research question for this paper was:

How can an M\&E framework be developed to measure a road freight transport system's sustainability in South Africa?

Prior to answering the research question in this article, research questions on what frameworks are available globally and in South Africa to measure the sustainability of RFTS as well as whether these frameworks measured sustainability holistically? (including all three sustainability dimensions) were asked and answered in [16]. Two systematic literature reviews were conducted. The search results as per the protocol of the first systematic literature review (SLR) returned 95 documents of which 31 peer reviewed articles met the inclusion criterion.

The findings were that many frameworks are available, but they are mainly in the form of Indicator Based Frameworks, Decision Making Frameworks, and Conceptual Frameworks. The second SLR found that the majority of the frameworks tended to lean more toward environmental assessments. A separate search including South Africa as part of the key words returned one result, namely a framework for rail freight revival in South Africa by Havenga et al. [29]. The findings from Lalendle's [16] SLRs determined that a holistic sustainability framework developed to assess sustainability of road transport systems in South Africa was needed, given the lack thereof from the two SLRs.

The development stage of the M\&E framework began by identifying the constructs and variables for the paper through literature on sustainability covered by Lalendle [16], followed by the gathering of transport sustainability definitions, relevant RFT indicators, selecting sustainability themes to be addressed by the framework, and lastly, setting goals for each theme. Once the framework was developed, it was sent out for review by road transport industry experts as part of the validation process. Clarification of the terminology used in the framework is explained in Table 1. The M\&E framework is shown in Tables 2-4. The method used for developing the M\&E Framework can be organized into three stages, as illustrated in Figure 3. 
Table 1. Abbreviations and explanations of $\{n\}$ contained in M\&E framework Tables 2-4.

\begin{tabular}{|c|c|}
\hline Abbreviation $\{\mathbf{n}\}$ & Explanation \\
\hline$\{1\}$ RFTS: & Road freight transport systems. \\
\hline$\{2\}$ Effecting consequences to traffic offences: & Driver tally, warnings, disciplinary action. \\
\hline$\{3\}$ RTMS certification: & $\begin{array}{l}\text { The Road Transport Management System is an industry-led, } \\
\text { government-supported, voluntary, self-regulation scheme that } \\
\text { encourages consignees, consignors, and road transport operators to } \\
\text { implement a management system (a set of standards) that } \\
\text { demonstrates compliance with the Road Traffic Regulations and } \\
\text { contributes to preserving road infrastructure, improving road safety } \\
\text { and increasing productivity. }\end{array}$ \\
\hline \{4\} SQAS: & Accreditation for Safety Quality Assessment for Sustainability. \\
\hline$\{5\}$ PBS: & Performance Based Standards. \\
\hline$\{6\}$ Night lights on vehicle body: & $\begin{array}{l}\text { Small additional lights on the body of a truck to make the truck more } \\
\text { visible at night or during bad weather conditions. }\end{array}$ \\
\hline \{7\} Safe loading and off-loading practices: & $\begin{array}{l}\text { For example, ensure the vehicle is stopped, braked, and stabilized, } \\
\text { loading areas are well lit and free from hazards, always have trained } \\
\text { personnel to use the loading and off-loading equipment. }\end{array}$ \\
\hline$\{8\}$ Road incidences: & $\begin{array}{l}\text { Loss of control of the vehicle causing an accident/crash or damage to } \\
\text { goods, collisions with people or objects, including fatalities, injuries, } \\
\text { or damage. }\end{array}$ \\
\hline$\{9\}$ Driver behavior: & $\begin{array}{l}\text { This refers to a driving style, how one brakes, accelerates, and } \\
\text { behaves on the road. }\end{array}$ \\
\hline$\{10\}$ Driver offenses: & $\begin{array}{l}\text { Violations caused by the driver, such as speeding, ignoring signage, } \\
\text { not wearing a seat belt, or driving under the influence of alcohol. }\end{array}$ \\
\hline$\{11\}$ Violations: & E.g. an unlicensed vehicle. \\
\hline \{12\} Loading incidences: & $\begin{array}{l}\text { Accidents, injuries, or fatalities caused by unsafe loading practices } \\
\text { e.g., overloading. }\end{array}$ \\
\hline$\{13\}$ Social cost: & Total cost to society; it includes private costs and external costs. \\
\hline$\{14\}$ RFT: & Road freight transport. \\
\hline$\{15\}$ Externality costs: & $\begin{array}{l}\text { Activities that incur a cost or negatively affect other parties and are } \\
\text { not financially incurred by the producer. }\end{array}$ \\
\hline$\{16\}$ Carbon tax: & A fee levied on fossil fuels with the intention to reduce emissions. \\
\hline$\{17\}$ Corporate social responsibility (CSR): & A business practice that integrates social accountability. \\
\hline$\{18\}$ Profit margin: & $\begin{array}{l}\text { The degree to which a company makes money, calculated by dividing } \\
\text { income by revenues. }\end{array}$ \\
\hline$\{19\}$ Eco-driving: & A driving style that minimizes fuel consumption and emissions. \\
\hline$\{20\}$ Applications: & Downloadable software applications. \\
\hline$\{21\}$ Loading rate: & Speed or time it takes to move cargo in or out of a truck or container. \\
\hline$\{22\}$ Empty leg km: & The distance traveled with no cargo being transported. \\
\hline$\{23\}$ Freight turnover rate: & The quantity of cargo multiplied by the distance transported. \\
\hline$\{24\}$ Cleaner fuels: & $\begin{array}{l}\text { Fuels that exert lesser greenhouse gas emissions (biodiesel, hydrogen, } \\
\text { compressed natural gas (CNG)). }\end{array}$ \\
\hline$\{25\}$ Recycle waste material: & To reuse or repurpose waste materials, e.g., tires and parts. \\
\hline
\end{tabular}


Table 2. Social dimension of RFTS M\&E framework.

\begin{tabular}{|c|c|c|c|c|c|}
\hline & Themes & Strategic Objective/Goal & Input & Output & Indicators \\
\hline \multirow[t]{3}{*}{ Social } & Safety & $\begin{array}{l}\text { Provide and maintain safe systems of } \\
\text { work for the driver and vehicle } \\
\text { through effective safety } \\
\text { management practices. } \\
\text { Decrease the number of annual } \\
\text { fatalities and injuries recorded as } \\
\text { relating to one's RFTS }\{1\} .\end{array}$ & $\begin{array}{l}\text { Reasonable driving hours. } \\
\text { Monitoring and effecting consequences of } \\
\text { traffic offenses }\{2\} \text {. } \\
\text { Driver training and periodic retraining. } \\
\text { RTMS certification }\{3\} \text {. } \\
\text { SQAS accreditation }\{4\} \text {. } \\
\text { Roadworthy vehicles. } \\
\text { Regular maintenance on vehicles. } \\
\text { Vehicle safety technology (e.g., remote } \\
\text { speed sensing, collision damage } \\
\text { mitigation braking system (CDMBS) and } \\
\text { tracking devices). } \\
\text { PBS for the design and improved safety } \\
\text { of vehicles }\{5\} \text {. } \\
\text { Night lights on vehicles }\{6\} \text {. } \\
\text { Safe loading and off-loading practices }\{7\} .\end{array}$ & $\begin{array}{l}\text { Non-fatigued drivers. } \\
\text { Reduction in the number of road } \\
\text { incidences }\{8\} \text {. } \\
\text { Improved driver behavior }\{9\} \text {. } \\
\text { A road management system that promotes } \\
\text { safety and efficiency. } \\
\text { A decrease in vehicle breakdowns. } \\
\text { Safer road environment. }\end{array}$ & $\begin{array}{l}\text { No. of crashes/accidents and injuries caused by } \\
\text { one's RFTS annually. } \\
\text { No. of driver offenses }\{10\} \text { reported annually. } \\
\text { No. of road violations }\{11\} \text { registered annually. } \\
\text { No. of vehicle technology interventions. } \\
\text { No. of loading incidences }\{12\} \text {. }\end{array}$ \\
\hline & Stakeholders & $\begin{array}{l}\text { Stakeholders are considered } \\
\text { concerning RFTS decisions that affect } \\
\text { them directly. } \\
\text { There is clarity of responsibilities } \\
\text { among stakeholders. }\end{array}$ & $\begin{array}{l}\text { Consultation meetings with stakeholders } \\
\text { (e.g., freight owner, agents, consumer, } \\
\text { and government). } \\
\text { Collaborative tools where stakeholders } \\
\text { can contribute their inputs. }\end{array}$ & RFTS designed to incorporate stakeholders. & No. of meetings held with stakeholders. \\
\hline & Cost Considerations & $\begin{array}{l}\text { Companies take responsibility for } \\
\text { their full social cost }\{13\} \text { by mitigating } \\
\text { the passing on of RFT }\{14\} \\
\text { externalities costs }\{15\} \text { to society. }\end{array}$ & $\begin{array}{l}\text { Carbon Tax }\{16\} \text {. } \\
\text { Social and environmentally friendly } \\
\text { RFTS initiatives. } \\
\text { Corporate social responsibility (CSR) }\{17\} \text {. }\end{array}$ & $\begin{array}{l}\text { Companies and end consumers bearing the } \\
\text { cost of air pollution, congestion, and } \\
\text { crashes caused due to operations. }\end{array}$ & $\begin{array}{l}\text { Amount of carbon tax paid. } \\
\text { No. of social or environmental initiatives. } \\
\text { Impact of CSR. }\end{array}$ \\
\hline
\end{tabular}


Table 3. Economic dimension of RFTS M\&E framework.

\begin{tabular}{|c|c|c|c|c|c|}
\hline & Themes & Strategic Objective/Goal & Input & Output & Indicators \\
\hline \multirow{4}{*}{ Economic } & Socio-economic & $\begin{array}{l}\text { Transport being a catalyst of } \\
\text { socio-economic growth and } \\
\text { development that benefits societies }\end{array}$ & $\begin{array}{l}\text { Human and physical capital } \\
\text { Business growth/expansion. }\end{array}$ & $\begin{array}{l}\text { Increased trade } \\
\text { Access to goods } \\
\text { Employment opportunities }\end{array}$ & $\begin{array}{l}\text { Market share growth } \\
\text { One's RFTS's contribution to GDP } \\
\text { No. of employees }\end{array}$ \\
\hline & Cost Considerations & $\begin{array}{l}\text { Generate profits from operations } \\
\text { Continuous productivity and growth }\end{array}$ & $\begin{array}{l}\text { Financial, human, and physical capital } \\
\text { Strengthen customer relationships } \\
\text { Offer competitive pricing }\end{array}$ & $\begin{array}{l}\text { Income is greater than expenses } \\
\text { Increase in productivity } \\
\text { Positive Return on Investment (ROI) } \\
\text { Expanded market share }\end{array}$ & $\begin{array}{l}\text { Profit margin }\{18\} . \\
\text { Output per unit of input } \\
\text { ROI = Investment gain/Investment cost } \\
\text { Increase in customer portfolio. }\end{array}$ \\
\hline & Operational Efficiency & $\begin{array}{l}\text { To generate income or outputs or } \\
\text { returns equivalent or greater, for } \\
\text { the same, or lower operating costs } \\
\text { Decrease the time and money lost } \\
\text { due to congestion. } \\
\text { Improved delivery process. }\end{array}$ & $\begin{array}{l}\text { Eco-driving }\{19\} \text {. } \\
\text { Loading facilities (loading and } \\
\text { unloading equipment and space). } \\
\text { Efficient loading and unloading } \\
\text { plan/schedule } \\
\text { Route planning } \\
\text { Seek freight to transport for trips that } \\
\text { usually return empty Alternatively sign } \\
\text { up to Apps }\{20\} \text { where one can bid to } \\
\text { transport freight. }\end{array}$ & $\begin{array}{l}\text { Decreased fuel consumption. } \\
\text { Increased loading rate }\{21\} . \\
\text { Less GHG emissions } \\
\text { Reduced empty leg kms }\{22\} \text {, } \\
\text { (which in turn decreases costs and } \\
\text { increases efficiency). }\end{array}$ & $\begin{array}{l}\text { Freight } \mathrm{km} \text { traveled/Fuel expense } \\
\text { The number of vehicles with } \\
\text { efficiency technology } \\
\text { The number of vehicles using cleaner energy } \\
\text { No. people needed to off load or load a } \\
\text { container or truck. } \\
\text { The time it takes to load or off-load containers } \\
\text { No. of containers that can be loaded or } \\
\text { off-loaded in a day. } \\
\text { Freight turnover rate (Tons } x \mathrm{~km})\{23\} \text {. } \\
\text { No. of annual empty kms traveled. }\end{array}$ \\
\hline & $\begin{array}{l}\text { Modal Choice \& } \\
\text { Competitiveness }\end{array}$ & $\begin{array}{l}\text { Offer modal choice that is } \\
\text { competitive and boosts } \\
\text { socio-economic development }\end{array}$ & $\begin{array}{l}\text { Fair and competitive pricing for the } \\
\text { movement of freight. } \\
\text { Maintenance of physical assets } \\
\text { Reinvestment into the business }\end{array}$ & $\begin{array}{l}\text { Affordable freight transportation prices. } \\
\text { Physical assets that are in good condition } \\
\text { Capacity to meet demand. }\end{array}$ & \\
\hline
\end{tabular}


Table 4. Environmental dimension of RFTS M\&E framework.

\begin{tabular}{|c|c|c|c|c|c|}
\hline & Themes & Strategic Objective/Goal & Input & Output & Indicators \\
\hline \multirow{3}{*}{ Environmental } & Emissions & $\begin{array}{l}\text { Decrease the business's RFTS } \\
\text { emissions by } 40-50 \% \text { by } 2050 \text {. } \\
\text { The national target is a total of } \\
5 \% \text { for the transport sector. }\end{array}$ & $\begin{array}{l}\text { Pollution control technology } \\
\text { Cleaner fuels }\{24\} \text {. } \\
\text { Company goals and targets } \\
\text { strategically aimed at } \\
\text { contributing to reducing } \\
\text { emissions in the RFT sector. }\end{array}$ & $\begin{array}{l}\text { A decrease in emissions } \\
\text { Cleaner emissions }\end{array}$ & $\begin{array}{l}\text { Annual fuel consumption (in liters) } \\
\text { No. of vehicles that use cleaner or } \\
\text { renewable fuels. }\end{array}$ \\
\hline & Resource consumption & $\begin{array}{l}\text { Minimizing waste and } \\
\text { consumption of natural } \\
\text { resources, and promote their } \\
\text { use in an ecological and } \\
\text { sustainable manner. }\end{array}$ & $\begin{array}{l}\text { Recycle waste material }\{25\} . \\
\text { Reuse and refurbish materials. }\end{array}$ & $\begin{array}{l}\text { Using natural resources at } \\
\text { rates equal to or less than the } \\
\text { rate of replenishment. }\end{array}$ & $\begin{array}{l}\text { Annual recycled tons. } \\
\text { Annual reused or refurbished tons. } \\
\text { Freight tonnes/Energy used. } \\
\text { Km traveled/Energy used. }\end{array}$ \\
\hline & Preservation for the Future & $\begin{array}{l}\text { Implement company policy } \\
\text { that supports sustainability } \\
\text { initiatives and protecting the } \\
\text { environment for the benefit of } \\
\text { present and future generations. }\end{array}$ & $\begin{array}{l}\text { Company policy and initiatives } \\
\text { geared at sustainability. }\end{array}$ & Conservation of resources. & $\begin{array}{l}\text { Cost } \% \text { of sustainability initiatives } \\
\text { the company has embarked on. }\end{array}$ \\
\hline
\end{tabular}



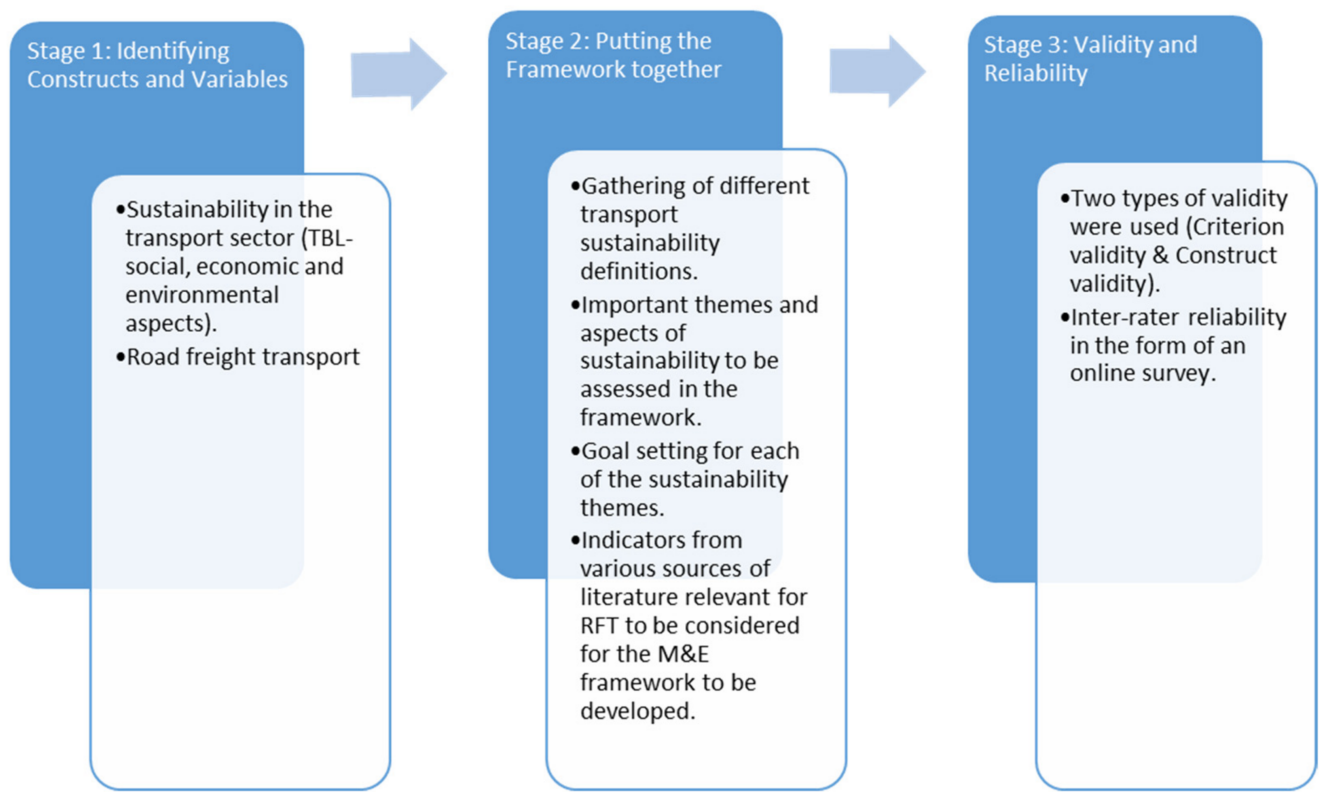

Figure 3. Research design breakdown (Stage 1-3).

\section{Stage 1: Identifying Constructs and Variables}

Sustainability was the complex construct focused on in the field of road freight transport. According to Statistics Solutions [30], breaking down a construct into a measurable form is the development of variables. The process of developing variables from constructs is usually seen to occur in the form of an operational definition. Lalendle [16] formulated an operational definition for sustainability in the transport sector. It gives details of features and elements that must be present for sustainability in the transport sector to be evident. The observable variables are the triple bottom line (TBL), which incorporates social, economic, and environmental dimensions of sustainability within road freight transport.

Stage 2: Putting the Framework Together

The sustainability themes and content within the framework were guided by the operational definition of sustainability in the transport sector, and the aspirations towards sustainable transport held by the South African Government. Furthermore, literature from Lalendle's systematic literature review (SLR) and findings from the research questions were incorporated [16].

The framework adapted the sustainability framework of Toth-Szabo and Várhelyi [31] as a structural guide for developing the M\&E sustainability assessment framework for RFTS in South Africa. It was the structural layout particularly of the sustainability dimensions, goals, inputs, and outputs that was adapted. The structure assisted in the layout to assign the goals/objectives, inputs, outputs, and measures related to the selected sustainability themes used in the development of the M\&E sustainability assessment framework. The framework was developed for the freight transporter to assess the level of their system's sustainability.

Figure 4 illustrates how the inputs were used in the development of the framework.

Stage 3: Validity and Reliability

Two validity types were used in this study to validate measures selected for the final M\&E sustainability assessment framework. Criterion validity was used to predict if there were correlations among the variables of the framework and measures and Construct validity analyzed the accuracy of the construct developed. The measures in the developed framework related to variables in the sustainability framework assessment, and were selected based on construct validity to ensure what will be measured relates back to either the goals, inputs, or outputs within the said framework. 


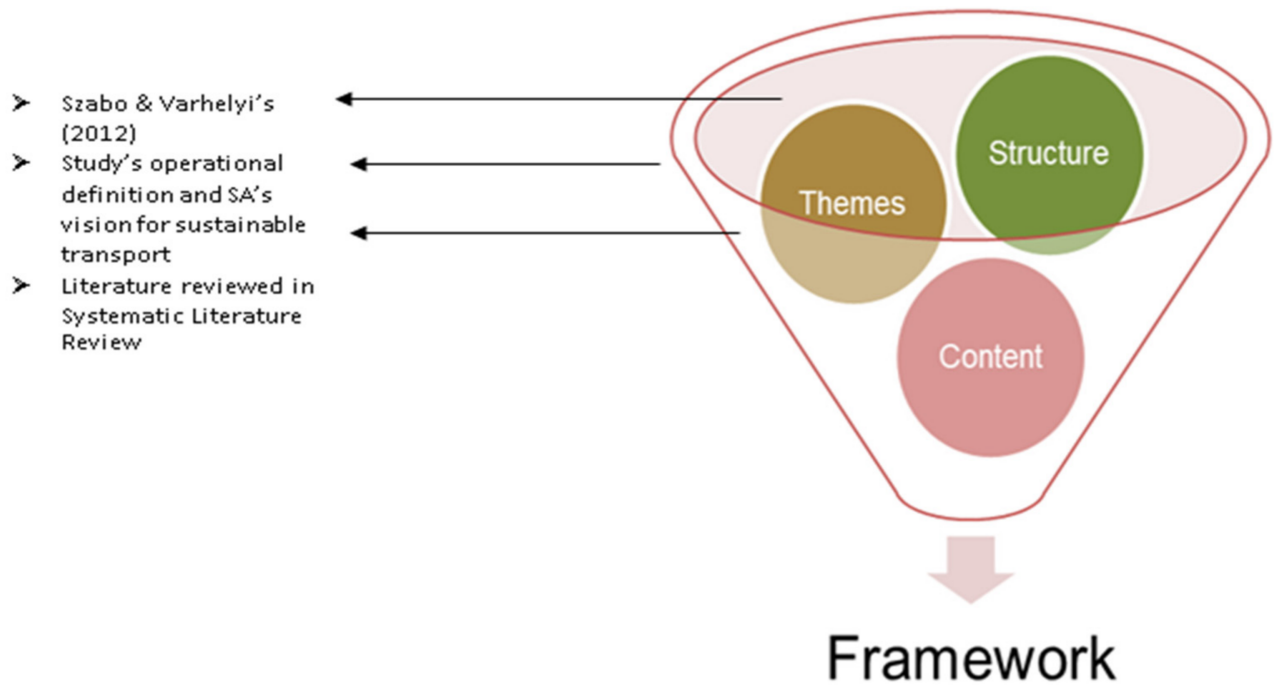

Figure 4. Inputs used in the framework.

Lastly, an inter-rater reliability check was used to rate the developed M\&E sustainability assessment framework. This type of reliability check validated the consistency in rating [32]. It is a useful assessment tool, particularly in judging activities conducted by humans [33]. Nine industry experts were requested to review the developed $M \& E$ sustainability assessment framework by means of a survey process to validate the relevance and credibility of the sustainability framework for RFTS in South Africa. The ratings were compared to determine consistency in the raters' feedback.

\section{Development of the M\&E Framework}

The development of the framework started by investigating how sustainability is defined in the transport sector. From that investigation, sustainability themes emerged and an operational definition was constructed. Defining what sustainability means in the transport sector assisted in laying down the requirements needed to reach the goal. Latham's [34] article on goal-setting theory emphasizes the importance of clear goal definitions and how that improves performance. Clearly defined goals give direction and enable one to measure the resulting performance. If the reality does not resemble the definition or vision of sustainability in the transport sector, then sustainability in the transport sector would not be achieved. Therefore, defining sustainability in the transport sector was an important starting point to gather the required standards, and to be able to measure performance according to the goal. The operational definition constructed by [16] of sustainability in the transport sector is as follows:

"A sustainable transport system is one that is accessible spatially allowing mobility needs to be met safely and affordably with social cost considerations (private cost and cost of externalities). The system operates efficiently with infrastructure that is an asset to communities, offering a modal choice that is competitive and boosts socio-economic development; ensuring future generations are not compromised to cater to the needs of current societies. Sustainable transport limits the emission of air pollution, noise pollution, and GHG's. It minimizes the use of land, consumption of non-renewable and renewable resources as well as material resources needed to support the transport system. It minimizes waste, reuses, and recycles its components. It decreases its impact on environments, protecting ecosystems, and the global climate. Sustainable transport systems support the economic, social, and environmental pillars and are designed to involve stakeholders".

A transport system that meets the description of this operational definition would be sustainable. The definition was constructed from 16 definitions found in the literature on 
transport sustainability worldwide, and encompasses all the themes brought forward by the author definitions in this study. The National Transport Policy White Paper of the South African Department of Transport [35] and the revised draft white paper [8], envisioned the transport system in South Africa as:

"Government will provide for a transport system that will facilitate the movement of goods and people; enable equitable access to personal economic opportunities and social services; support economic and environmental sustainability and inclusive growth, and advance national, regional and global competitiveness of the country."

In order to achieve this, government acknowledges that there must be adequate supply of transport infrastructure and services to meet the demand. Furthermore, that the users should receive accessible, cost effective, time-efficient and reliable, as well as safe and secure service.

The South African government's vision of sustainable transport is not dissimilar to the operational definition provided. Similarities and differences are shown in Figure 5.

\section{Study's Operational Definition}

$\square$ Acessibility
$\square$ Meeting safety needs
$\square$ System efficency
$\square$ Infrastructure that is an assest
$\square \begin{aligned} & \text { Boosts socio-economic } \\ & \text { development }\end{aligned}$
$\square$ Cost considerations
$\square \begin{aligned} & \text { Competitive modal choice } \\ & \text { Reduced emissions, land use, } \\ & \text { waste and resource } \\ & \text { consumption }\end{aligned}$
$\begin{aligned} & \text { Protecting ecosystems } \\ & \text { Not compromising future } \\ & \text { generations }\end{aligned}$
Involves stakeholders
Support economic, social and
environmental pillars

\section{South Africa's Vision}

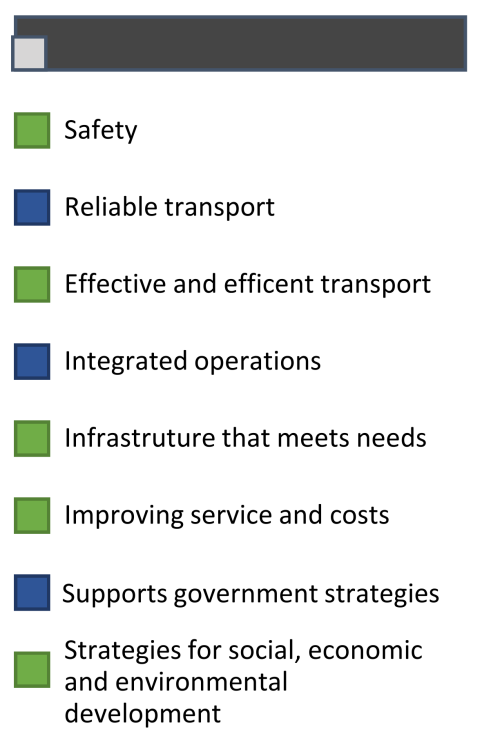

Legend

$\square$ Difference

Similarities

Figure 5. Key themes from the study's operational definition and South Africa's vision for sustainability and their differences and similarities [16].

\section{Framework Structure}

Numbers 1-25 in Table 1 are footnotes that correspond with the numbers, $\{n\}$, contained in the social, economic, and environmental dimensions of the RFTS M\&E framework in Tables 2-4. The footnotes provide a brief explanation of concepts referred to in Tables 2-4 that may not otherwise be clear.

The first column of the framework (as included in Tables 2-4) contains the three dimensions of the TBL being focused on respectively. All three dimensions of the TBL are addressed in the framework, namely: the social (Table 2), economic (Table 3), and environmental (Table 4) dimensions of sustainability. The second column of the framework 
contains the 10 themes selected that emerged from the operational definition, as well as themes related to South Africa's vision for sustainable transport. Thereafter, it follows the strategic objective or goal for each theme, followed by the inputs needed toward achieving the goal, the outputs of the framework, and possible indicators.

The Indicators column in the framework are suggested measures found in articles reviewed in [16] SLR, and therefore, are limited. These indicators were selected for their relevance as measures for determining the input, output, or goal within the theme it contained.

The framework was developed to be used by road freight transporters, operating in South Africa at a regional, national, or international level. Many road freight operators in South Africa also operate into sub-Saharan Africa, so the framework would be most likely applicable to and transferrable into this region.

The World Bank [36] highlights that Africa's development is highly dependent on adequate and reliable road systems. The lack of road capacity, poor infrastructure, traffic congestion, delays, and road crash fatalities are amongst the identified challenges that need urgent solutions in the African region. These listed road freight challenges link into the three sustainability dimensions addressed by the framework.

Environmentally: Vehicle pollutants in the form of carbon monoxide, hydrocarbons, nitrogen oxides, sulfur dioxide, and other toxins released from vehicle exhausts compromise the air quality leaving direct and indirect adverse health effects [37]. This triggered the attention of governing authorities to initiate some form of regulatory control/taxes on transport emissions.

Socially: Road fatalities are one of the alarmingly high occurrences on the continent. Although Africa only contributes 2 percent of the world's vehicle population, it has the highest global road crash fatality rate, estimated at 24.1 per 100,000 of the population [38]. Some causes can be attributed as a result of congestion, poor road conditions, and road deterioration, impending on the built and natural environment. Road crashes are harmful to the persons involved in the incident, the infrastructure, and natural environment. Approximately 27 countries in Sub-Saharan Africa have road funds for new roads and maintenance of existing roads, and approximately 20 road agencies for their sustainable management [39]. However, the current road network status on the continent implies funding levels are either insufficient to meet the needs of the region or that there may be other managerial challenges associated with the progression to delivering adequate and reliable roads.

Economically: The UNECA [40] reported that firms in Africa lose 13 percent of their sales due to infrastructural, credit, and regulatory inefficiencies; however, it must be noted that this percentage differs across firms and countries. With an unreliable freight transport system many businesses overstock goods, incurring additional costs to ensure product availability. Some goals within the sustainability themes of the M\&E framework speak to the challenges referred to, faced in multiple regions within Africa.

Therefore, road freight operators within the different African regions should adapt the framework and use it as a tool to assess their RFTS changes, progress, and areas of non-compliance in line with global sustainability in the transport sector, reflected in the operational definition and their country's transport sustainability goals, if they are much different from that of South Africa.

It is recommended that each RFTS that utilizes the framework monitor the inputs for periodic evaluation. The framework was developed with the intention of annual assessments to be conducted by designated personnel or a team within a company/organization that seeks to assess and improve the sustainability of their RFTS.

\section{Framework Review}

The M\&E framework developed to assess the sustainability of road freight transporters in South Africa was validated through a review process involving nine industry experts. Their profiles are shown in Table 5. An information pack was prepared as input material for the industry experts, which explained the framework's development process, the 
draft framework, and which also included the review questionnaire (Appendix A). The appropriate sample size for the expert reviews had to be determined. Non-probability sampling was used for the expert reviews. Saunders et al. [41] suggest a sample size of 5-25 participants is required when conducting expert reviews. The information pack and review questionnaire were sent to nine experts in the road freight transport industry. The detailed feedback and inputs provided by these nine participants was valuable and much appreciated.

Table 5. Background details of survey participants.

\begin{tabular}{|c|c|c|}
\hline Participant & Occupation & Background/Training \\
\hline 1 & Group SHEQ Manager & $\begin{array}{l}15 \text { years SHEQ Management- } \\
\text { Logistics industry }\end{array}$ \\
\hline 2 & Transport and Logistics Consultant & $\begin{array}{c}\text { More than } 50 \text { years in and around } \\
\text { the road freight industry and } \\
\text { related value chains }\end{array}$ \\
\hline 3 & Manager at a transport company & M Com Logistics Management \\
\hline 4 & Chief Innovation Officer & Engineer \\
\hline 5 & $\mathrm{CEO}$ and $\mathrm{CIO}$ & $\begin{array}{c}\text { CPA (North America), Fellow of } \\
\text { ACCA, CAIB (SA), Former CFO } \\
\text { of Super Group Coal. }\end{array}$ \\
\hline 6 & Principal Research Engineer & Mechanical Engineering \\
\hline 7 & $\begin{array}{l}\text { Financial Manager at a transport } \\
\text { company }\end{array}$ & Finance \\
\hline 8 & Researcher & Data modeler \\
\hline 9 & Principal researcher: smart mobility & $\begin{array}{l}\text { Operations research, information } \\
\text { systems, industrial systems }\end{array}$ \\
\hline
\end{tabular}

A summary of the review is provided below:

There were three questions linked to the structure and flow of the framework as shown in Table 6. Seven of the respondents agreed that it is easy to understand the framework and reflected that they found it easy to work through the framework. Eight respondents experienced it as having a logical flow of the horizontal headings (Themes, Goals/Objectives, Inputs, Outputs, and Indicators).

Table 7 is linked to appropriateness in relation to the themes, the framework being a guide for the sustainability of RFTS, and assisting toward adopting a more holistic approach to sustainability. Three respondents were indifferent about the sustainability themes used in the vertical headings in Tables 2-4. As to whether the themes contribute towards achieving holistic sustainability, six of the nine respondents thought they did. Eight out of the nine experts viewed the framework as having the potential to assist toward adapting holistic sustainability of RFTS. The one who disagreed added that sustainability in RFTS would be more effectively assisted by government and fuel producers. The authors agree that dynamic interventions and guidance from government would greatly benefit this move toward a more sustainable RFTS; however, in the absence of that, the M\&E framework would facilitate industry to manage their own interventions. Furthermore, five of the nine respondents agreed that the framework guides sustainability in RFTS and the remaining four were neutral. 
Table 6. Summary response on structure and flow.

\begin{tabular}{cccc}
\hline & \multicolumn{3}{c}{ Structure \& Flow } \\
\hline Question & \multicolumn{3}{c}{ Is the framework easy to understand? } \\
\hline Likert Scale & Yes & Neutral & No \\
\hline Response & 7 & 1 & 1 \\
\hline Question & Is there a logical flow between the horizontal headings of the framework? \\
\hline Likert Scale & Yes & Neutral & No \\
\hline Response & 8 & 1 & No \\
\hline Question & \multicolumn{2}{c}{ Is the framework easy to work through? } \\
\hline Likert Scale & Yes & Neutral & 0 \\
\hline Response & 7 & 2 &
\end{tabular}

Table 7. Summary response of appropriateness of the framework.

\begin{tabular}{|c|c|c|c|}
\hline \multicolumn{4}{|c|}{ Appropriateness } \\
\hline Question & \multicolumn{3}{|c|}{ Does the framework guide sustainability in RFTS? } \\
\hline Likert Scale & Yes & Neutral & No \\
\hline Response & 5 & 4 & 0 \\
\hline Question & \multicolumn{3}{|c|}{$\begin{array}{l}\text { Does the framework assist South African transporters to adapt their } \\
\text { RFTS towards more holistic sustainability? }\end{array}$} \\
\hline Likert Scale & Yes & Neutral & No \\
\hline Response & 8 & 0 & 1 \\
\hline Question & \multicolumn{3}{|c|}{$\begin{array}{l}\text { Do the different themes of the sustainability dimensions contribute to } \\
\text { achieving holistic sustainability? }\end{array}$} \\
\hline Likert Scale & Yes & Neutral & No \\
\hline Response & 6 & 3 & 0 \\
\hline
\end{tabular}

With regard to the inputs and goals, the respondents were requested to state whether each input is implementable by road freight transporters and if each goal is attainable. The results are summarized in Figure 6.

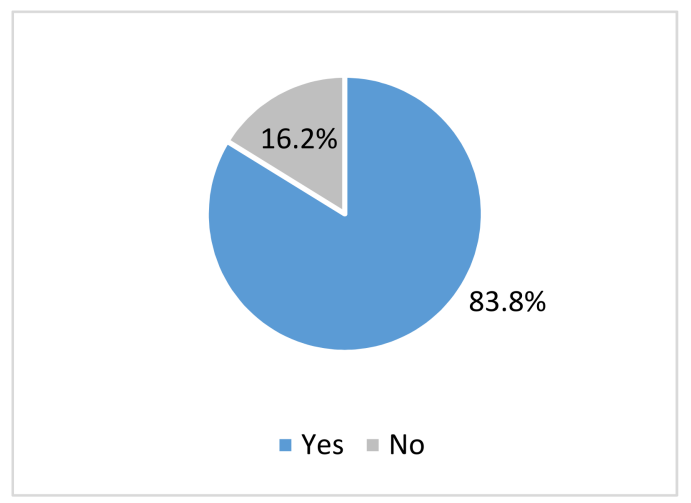

(a)

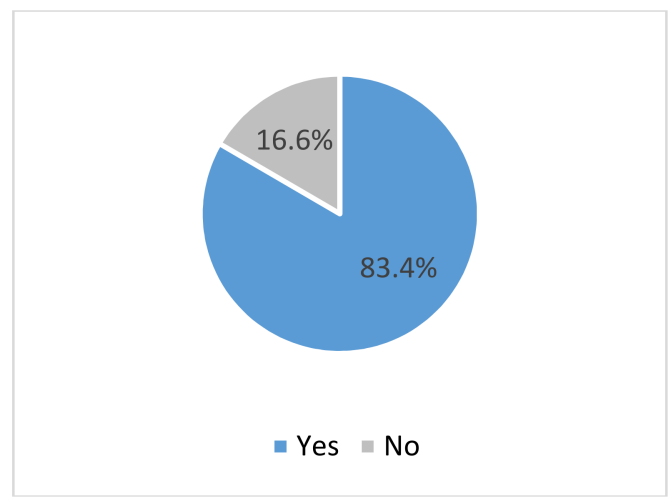

(b)

Figure 6. Summary response on feasibility. (a) Shows the results of the question: Are the inputs implementable by South African transporters? (a) Shows that $83.8 \%$ agreed in the affirmative to the question. (b) Shows the results of the question: Are the strategic goals realistic/attainable for the South African environment? (b) Shows that $83.4 \%$ answered yes. 
As shown in Table 8, seven out of the nine respondents regarded the developed framework to be aligned to the study's operational definition of sustainability in the transport sector, which encompasses all the key themes and elements contained in the definitions the study investigated. The second question, related to whether the framework aligned to government's vision of transport sustainability, showed that five of the nine respondents were in consensus that the framework aligns to the South African vision, whilst four of the nine were indifferent.

Table 8. Summary response of how the framework aligns to the operation definition and South Africa's vision for transport sustainability.

\begin{tabular}{cccc}
\hline & \multicolumn{3}{c}{ Alignment } \\
\hline Question & Are results for if the M\&E framework aligned with the operational definition? \\
\hline Likert Scale & Yes & Neutral & No \\
\hline Response & 7 & 2 & 0 \\
\hline Question & Are results for if the M\&E framework aligned with the government's vision? \\
\hline Likert Scale & Yes & Neutral & No \\
\hline Response & 5 & 4 & 0 \\
\hline
\end{tabular}

Inputs to improve the framework were requested from the experts. Their suggestions included technological aspects such as the state of readiness and adoption, addressing fraudulent licensing of vehicles and drivers, as well as compliance of vehicle designs. Additional suggestions in Table 9 were added to the M\&E sustainability framework in Tables 2-4.

Table 9. Inputs from the respondents.

\begin{tabular}{cc}
\hline & $\begin{array}{r}\text { Under operational efficiency, PBS was incorporated for design } \\
\text { and improved safety. }\end{array}$ \\
\cline { 2 - 3 } Incorporated Feedback & $\begin{array}{r}\text { Safety Quality Assessment for Sustainability (SQAS) } \\
\text { accreditation as an input under the safety theme. }\end{array}$ \\
\cline { 2 - 3 } $\begin{array}{c}\text { Under the economic dimension, include a profitability theme } \\
\text { for evaluation. }\end{array}$ & Driver retraining was suggested as an addition. \\
\hline
\end{tabular}

Furthermore, the respondents were asked if they would need an incentive to implement a sustainability framework for RFTS. Five out of the nine respondents said no. One respondent was unsure and the three that answered yes, mentioned their interest of incentives in the form of rebates, a decrease or subsidy on Sasria insurance (a special third-party risk cover to all individuals and businesses that own assets in South Africa, as well as government entities), and/or relief on a carbon tax for compliant companies.

The survey sought to obtain feedback from industry experts for the validity and reliability of the developed framework. Overall, the respondents' feedback was positive toward the framework; their feedback on additional inputs, themes, and measures were considered, and where suitable, incorporated into Tables $2-4$ as presented in this paper.

\section{Conclusions and Future Work}

Road transport contributes the most towards negative externalities within the transport sector, and hence, it is identified as the transport mode that would contribute significantly to addressing the unsustainability within this sector. Latham [34] stresses the importance of goal setting in order to give direction and measure performance based on one's goal; this formed a fundamental component in the framework's development. Theoretically, sustainability for transport systems is clearly defined and described by the study's 
operational definition, as well as in documentation of the South African Department of Transport (DoT).

An M\&E framework for South African road freight transporters was developed, which encompasses transport sustainability and the South African government's vision for sustainability within the transport sector. Goals, inputs, outputs, and indicators were put together for the sustainability assessment of RFTS in South Africa. Industry members can use the framework to frequently measure their operational sustainability on all three levels of the triple bottom line. The balanced view developed within the framework would enable senior planners and asset managers to engage in evidence based decision making related to the total RFTS sustainability of their organization. Thus, implementing the M\&E framework could influence infrastructure investment decisions toward a more sustainable RFTS imperative for the organization, their supply chains, and the wider region they operate in.

Finally, the developed framework was reviewed by industry experts who assessed the framework and shared their inputs. These knowledgeable individuals deemed the M\&E framework as being implementable, the strategic goals as being attainable, and aligned with the governments' vision.

A number of recommendations for future work were identified and are elaborated on below regarding the RFTS M\&E sustainability framework developed in this study. These are related to: customization for organizations; providing performance targets; applicability of the framework in other developing countries; a framework for government to track their sustainability progress regarding RFTS; and calculation of detailed economic benefits.

The compilation of measures within the framework was limited, as they were elicited from the systematic literature review from which this article stems as well as inputs from the expert review. Future work can therefore focus on the indicator aspect of the framework by acquiring more indicators from other sources, and incorporate performance targets as a scoring element of the framework so companies can quantify how compliant they are for benchmarking purposes.

Transport systems are unique and operate differently [23]. It would thus be fitting to develop a range of frameworks for the South African context. This is necessary so that road freight transporters operating in South Africa can have a variety of options for sustainability assessment frameworks that are appropriate for their specific transport system, such as size of the company and types of services offered. Therefore, the generic framework shown in Tables 2-4 can be further customized into frameworks for specific subcategories of the road freight transport sector or customized by stakeholders to fit their own goals, inputs, outputs, and measures to assess the sustainability of their RFTS.

Furthermore, a framework could be developed for the South African government to track their progress in freight transport sustainability, as they are also a key role player with regard to road freight sustainability in South Africa. Similarly, other developing countries could research the challenges faced in their country's transport sector and adapt the M\&E framework to assess sustainability of RFTS in their territories.

Lastly, the potential financial benefits associated with the economic dimension of a sustainable RFTS is a critical success factor in the sector due to low margins and high competition. Therefore, the calculation of the monetary and tangible benefits of adopting a sustainability framework should be incorporated to demonstrate the positive correlation of sustainable practices and economic success.

Author Contributions: J.v.E. and L.G.-G. conceived the idea of the topic. C.L. wrote the manuscript with supervision from both L.G.-G. and J.v.E. who also critically reviewed and edited the manuscript. Conceptualization, C.L., L.G.-G., and J.v.E.; methodology, C.L.; data curation, C.L.; writing—original draft preparation, C.L.; writing - review and editing, C.L., L.G.-G., and J.v.E. All authors have read and agreed to the published version of the manuscript.

Funding: This research received no external funding. 
Institutional Review Board Statement: Ethical review and approval were waived for this study. The research was not linked to individuals or any personal accounts (or information). The Masters study was deemed as low ethical risk by the Departmental Ethics Screening Committee, and Ms Lalendle was granted permission to conduct the research for her Master's studies.

Informed Consent Statement: Verbal consent was obtained from all participants.

Data Availability Statement: Data supporting results can be found in Lalendle [16] accessible at https:/ / scholar.sun.ac.za/handle/10019.1/110087, accessed on 2 July 2021.

Conflicts of Interest: The authors declare no conflict of interest.

\section{Appendix A}

\section{Appendix A.1. Validation Questions}

The following questions serve to validate the framework. If you have any suggestions or comments to improve the framework, please feel free to include them.

Please copy and paste the link into your web browser to take the questionnaire online: https:/ / docs.google.com/forms/d/e/1FAIpQLScX2C-726PvcV1F9DyWWSUw2 izhqs7fJVuloXVMUIuG0bj0Sg/viewform (accessed on 4 November 2020).

\section{Participant name: \\ Email address: \\ Occupation: \\ Background:}

\section{Participant's Response}

(1) How important are the themes for each sustainability dimension?

Rank the 10 themes by marking with an X the importance of each sustainability theme, (1)—Representing most important and (10)—least important.

\begin{tabular}{|c|c|c|c|c|c|c|c|c|c|c|c|}
\hline & Themes & 1 & 2 & 3 & 4 & 5 & 6 & 7 & 8 & 9 & 10 \\
\hline \multirow{4}{*}{$\begin{array}{c}\text { Social } \\
\text { dimension }\end{array}$} & Safety & & & & & & & & & & \\
\hline & Stakeholders & & & & & & & & & & \\
\hline & $\begin{array}{c}\text { Social Cost } \\
\text { Considerations }\end{array}$ & & & & & & & & & & \\
\hline & Social economic & & & & & & & & & & \\
\hline \multirow{3}{*}{$\begin{array}{l}\text { Economic } \\
\text { dimension }\end{array}$} & Cost Considerations & & & & & & & & & & \\
\hline & Operational efficiency & & & & & & & & & & \\
\hline & $\begin{array}{l}\text { Modal Choice \& } \\
\text { Competitiveness }\end{array}$ & & & & & & & & & & \\
\hline \multirow{3}{*}{$\begin{array}{c}\text { Ecological } \\
\text { dimensions }\end{array}$} & Emissions & & & & & & & & & & \\
\hline & $\begin{array}{c}\text { Resource } \\
\text { Consumption }\end{array}$ & & & & & & & & & & \\
\hline & $\begin{array}{c}\text { Preservation of } \\
\text { the future }\end{array}$ & & & & & & & & & & \\
\hline
\end{tabular}

These questions relate to the design and usability of the framework. 


\begin{tabular}{|c|c|c|c|c|c|c|}
\hline & \multicolumn{6}{|c|}{ Participant's Response } \\
\hline & \multicolumn{6}{|c|}{ Mark with an $\mathrm{X}$ the on the statement you most agree with } \\
\hline \multirow{3}{*}{$\begin{array}{l}\text { Structure and } \\
\text { Process }\end{array}$} & Strongly agree & Agree & Neutral & Disagree & Strongly disagree & Comments \\
\hline & \multicolumn{6}{|c|}{ The framework is easy to understand? } \\
\hline & \multicolumn{6}{|c|}{ The framework is easy to work through? } \\
\hline
\end{tabular}

Is there a logical flow between the horizontal headings of the framework (strategic objectives, inputs, outputs and measures)?

The framework guides sustainability in RFTS?

Appropriateness

The different themes of the sustainability dimensions contribute to achieving holistic sustainability?

Are the inputs implementable by South African transporters?

Social dimension Inputs

Reasonable driving hours

Monitoring and effecting consequences to traffic offences [2].

RTMS certification [3].

Roadworthy vehicles.

Regular maintenance on vehicles.

Vehicle safety technology (e.g., remote speed sensing, collision damage mitigation braking system (CDMBS) and tracking devices).

Night lights on vehicles [4].

Safe loading and off-loading practices [5].

Consultation meetings with stakeholders (e.g., freight owner, agents, consumer, and government)

Collaborative tools where stakeholders can contribute their inputs. Carbon Tax [14].

Social and environmentally friendly RFTS initiatives.

Corporate social responsibility (CSR) [15].
Economic dimension Inputs

Human and physical capital.

Business growth/expansion.

Financial, human and physical capital.

Strengthen customer relationships.

Offer competitive pricing.

Eco driving [19].

Loading facilities (loading and unloading equipment and space).

Efficient loading and unloading plan/schedule.

Route planning

Seek freight to transport for trips that usually return empty. Alternatively sign up to Applications [20] where

one can bid to transport freight.

Fair and competitive pricing for the movement of freight.

Maintenance of physical assets.

Reinvestment into the business.
Ecological dimension Inputs

Pollution control technology. Cleaner fuels [24].

Company goals and targets strategically aimed at contributing to reducing emissions in the RFT sector.

Recycle waste material [25].

Reuse and refurbish materials.

Company policy and initiatives geared at sustainability. 
The framework aligns with the South African government's transport sustainability goals?

"Provide safe, reliable, effective, efficient, and fully integrated transport operations and infrastructure, which will best meet the needs of freight and passenger customers at improving levels of service and cost in a fashion which supports government strategies for economic and social development whilst being environmentally and economically sustainable".-DOT (2007;1996)

\begin{tabular}{c} 
Strongly agree Agree Nee \\
\hline The framework aligns with this study's transport sustainability definition? \\
\hline A sustainable transport system is one that is accessible spatially allowing mobility needs to be met safely and affordably with social cost considerations (private cost \\
and cost of externalities). The system operates efficiently with infrastructure that is an asset to communities, offering modal choice that is competitive and boosts \\
socio-economic development, ensuring future generations are not compromised to cater for the needs of current societies. Sustainable transport limits the emission \\
of air pollution, noise pollution and GHGs. It reduces the use of land, consumption of non-renewable, and renewable resources as well as material resources needed \\
to support the transport system. It minimizes waste, reuses, and recycles its components. It decreases its impact on environments, protecting ecosystems, and the \\
global climate. Sustainable transport systems support the economic, social and environmental pillars and are designed to involve stakeholders.
\end{tabular}

(Definition developed by the author for the purpose of the study)

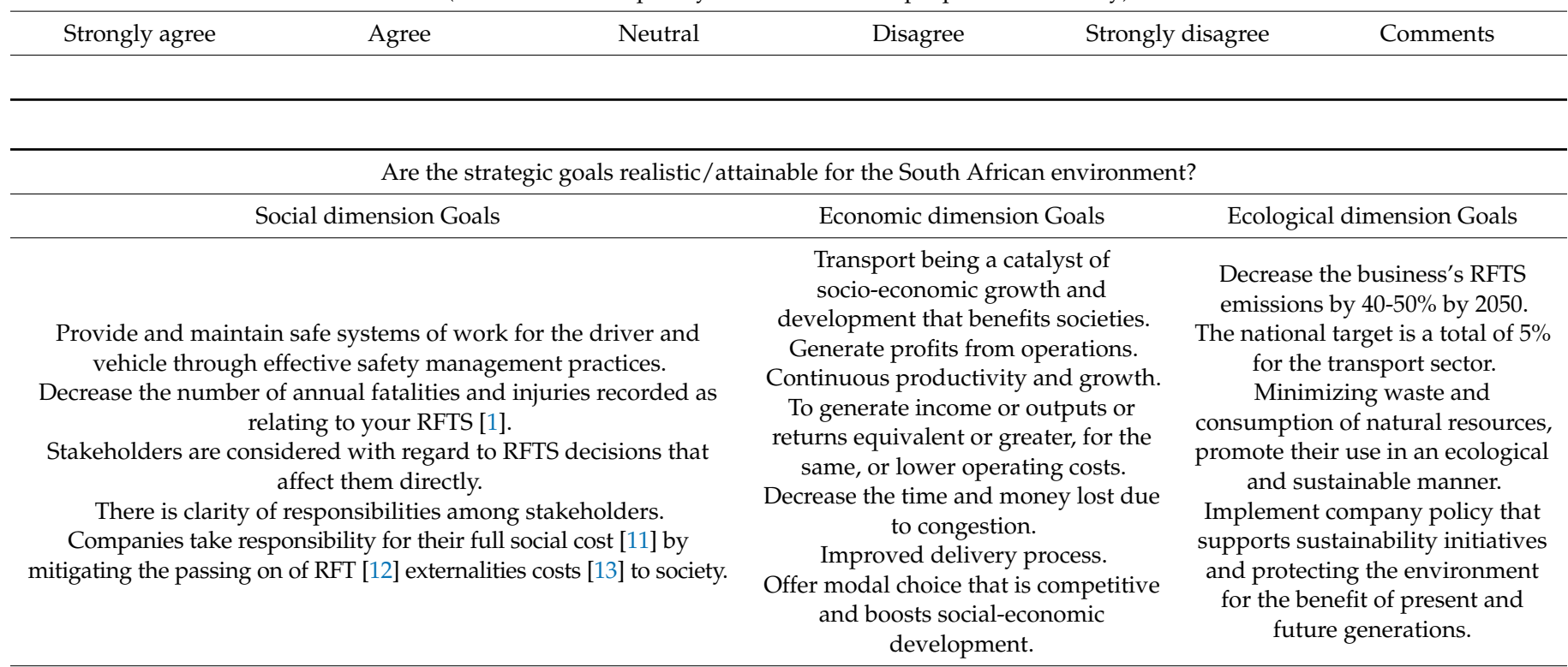

\begin{tabular}{cc} 
Mark with an $X$ your answer below. & Comment if answered NO: \\
\hline YES & NO
\end{tabular}

Comment if answered NO:

Does the framework assist South African transporters to adapt their RFTS towards more holistic sustainability?

Mark with an $\mathrm{X}$ your answer below.

YES NO

Comment if answered NO:

Are there measures you use or know of in industry, relevant to the framework, that are not currently added

that you would like to see added in the framework?

Mark with an $\mathrm{X}$ your answer below.

Comment with the measure if answered YES:

YES NO

Do you have any inputs/suggestions for the improvement of the framework?

Mark with an $\mathrm{X}$ your answer below. $\quad$ Comment if answered YES:

YES NO 


\section{References}

1. Van Zyl, F.J. Freight transport in a changing environment: Implementation of deregulation. Int. J. Phys. Distrib. Logist. Manag. 1992, 22. [CrossRef]

2. Havenga, J.H.; Pienaar, W.J. The creation and application of a national freight flow model for South Africa. J. S. Afr. Inst. Civ. Eng. 2012, 54, 2-13.

3. Department of Transport. Transport Bulletin. 2015. Available online: https://www.transport.gov.za/documents/11623/89294/ Transport_Statistics_Bulletin_2015.pdf/584b1a84-3728-4b49-9576-b6c873b66bfc (accessed on 2 July 2021).

4. Department of Transport. Green Transport Strategy 2018-2050; Department of Transport: Pretoria, South Africa, 2018. Available online: https:/ / www.transport.gov.za/documents/11623/89294/Green_Transport_Strategy_2018_2050_onlineversion.pdf/71 e19f1d-259e-4c55-9b27-30db418f105a (accessed on 22 July 2020).

5. SA Venues. National Road of South Africa. 2021. Available online: https://www.sa-venues.com/maps/south-africa-nationalroads.htm (accessed on 16 June 2021).

6. Retallack, A.E.; Ostendorf, B. Current understanding of the effects of congestion on traffic accidents. Int. J. Environ. Res. Public Health 2019, 16, 3400. [CrossRef] [PubMed]

7. Merven, B.; Stone, A.; Hughes, A.; Cohen, B. Quantifying the Energy Needs of The Transport Sector for South Africa: A Bottom-Up Model; Energy Research Center, University of Cape Town: Cape Town, South Africa, 2012.

8. Department of Transport. Draft Roads Policy for South Africa. Republic of South Africa. 2017. Available online: https://www. rtmc.co.za/images/rtmc/docs/universal_access/Draft\%20Roads\%20Policy\%20for\%20South\%20Africa_March\%202017.pdf (accessed on 20 May 2021).

9. Andersson, J.; Holmberg, B. Reducing Environmental Impacts of Freight Transport Sector: The Case of the Czech Republic. Master's Thesis, Lund University, Lund, Sweden, 2005.

10. Demir, E.; Huang, Y.; Scholts, S.; Van Woensel, T. A selected review on the negative externalities of the freight transportation: Modeling and pricing. Transp. Res. Part E Logist. Transp. Rev. 2015, 77, 95-114. [CrossRef]

11. Townshend, M.; Ross, D. The cost of South Africa's road maintenance backlog is nearing ZAR417-billion. In Proceedings of the South African Transport Conference, Pretoria, South Africa, 8-11 July 2019.

12. Tavasszy, L.; De Jong, G. Modelling Freight Transport; Elsevier: London, UK, 2013.

13. Merven, B.; Hartley, F.; Ahjum, F. Road freight and energy in South Africa. SA-TIED Work. Pap. 2019, 60, 4.

14. Rodrigue, J.P. The Geography of Transport Systems; Routledge: Abingdon, UK, 2020.

15. Ivanov, D. Predicting the impacts of epidemic outbreaks on global supply chains: A simulation-based analysis on the coronavirus outbreak (COVID-19/SARS-CoV-2) case. Transp. Res. Part E Logist. Transp. Rev. 2020, 136, 101922. [CrossRef] [PubMed]

16. Lalendle, C. Development of a Monitoring and Evaluation Framework for the sustainability assessment of Road Freight Transport Systems in South Africa. Master's Thesis, Stellenbosch University, Stellenbosch, South Africa, 2021.

17. Loske, D. The impact of COVID-19 on transport volume and freight capacity dynamics: An empirical analysis in German food retail logistics. Transp. Res. Interdiscip. Perspect. 2020, 6, 100165. [CrossRef]

18. Liu, M.; Lee, C.C.; Choo, W.C. The response of the stock market to the announcement of global pandemic. Emerg. Mark. Financ. Trade 2020, 56, 3562-3577. [CrossRef]

19. Liu, X.T.; Pan, X.B.; Yin, C.Z. Pandemic, mobile payment, and household consumption: Micro-evidence from China. Emerg. Mark. Financ. Trade 2020, 56, 2378-2389. [CrossRef]

20. Crainic, T.G.; Ricciardi, N.; Storchi, G. Advanced freight transportation systems for congested urban areas. Transp. Res. Part C Emerg. Technol. 2004, 12, 119-137. [CrossRef]

21. StatsSA [Statistics South Africa]. Land Transport Survey, December Statistical Release P7162. Excel-Land Transport Survey Pretoria 2018, South Africa. 2018. Available online: http://www.statssa.gov.za/timeseriesdata/Excel/P7162\%20Land\%20 transport\%20survey\%20(201812).zip (accessed on 9 March 2019).

22. Definition of System; Merriam-Webster: Springfield, MA, USA. Available online: https://www.merriam-webster.com/ dictionary / system (accessed on 13 May 2021).

23. Centobelli, P.; Cerchione, R.; Esposito, E. Evaluating environmental sustainability strategies in freight transport and logistics industry. Bus. Strategy Environ. 2020, 29, 1563-1574. [CrossRef]

24. European Union. Sustainable Urban Mobility: European Policy, Practices and Solutions. Publications Office of The European Union: Luxembourg, 2017. Available online: https://ec.europa.eu/transport/sites/default/files/2017-sustainable-urbanmobility-european-policy-practice-and-solutions.pdf (accessed on 15 June 2021).

25. Onyango, L. Efficacy of Monitoring and Evaluation Framework on Implementation of Development Projects: A Comparative Analysis of Machakos and Embu Counties. Ph.D. Thesis, Kabarak University, Kabarak, Kenya, 2019.

26. Pollack, J. The Changing Paradigms of Project Management. Int. J. Proj. Manag. 2007, 5, 266-274. [CrossRef]

27. Dobrea RCCiocoiu, N.; Tipa, S. Investments Characteristics in Infrastructure Industry. Economia. Ser. Manag. 2010, 13, 204-210.

28. Kusek, J.Z.; Rist, R.C. Ten Steps to a Results-Based Monitoring and Evaluation System; The World Bank: Washington, DC, USA, 2004.

29. Havenga, J.H.; Pienaar, W. Framework for rail freight transport revival in South Africa. Corp. Ownersh. Control. 2011, 8, 451-460. [CrossRef] 
30. Statisticssolutions, Understanding the Difference between Constructs, Variables and Operational Definitions. Available online: https: //www.statisticssolutions.com/understanding-the-differences-between-constructs-variables-and-operational-definitions / (accessed on 22 November 2020).

31. Toth-Szabo, Z.; Várhelyi, A. Indicator framework for measuring sustainability of transport in the city. Procedia Soc. Behav. Sci. 2012, 48, 2035-2047. [CrossRef]

32. Saal, F.E.; Downey, R.G.; Lahey, M.A. Rating the ratings: Assessing the psychometric quality of rating data. Psychol. Bull. 1980, 88, 413. [CrossRef]

33. Landis, J.R.; Koch, G.G. The measurement of observer agreement for categorical data. Biometrics 1977, 33, 159-174. [CrossRef] [PubMed]

34. Latham, G.P. The motivational benefits of goal-setting. Acad. Manag. Perspect. 2004, 18, 126-129. [CrossRef]

35. Department of Transport. White paper on National Transport Policy of 20 August 1996. Republic of South Africa. Available online: https:/ / www.comair.co.za/Media/Comair / files/level-playing-field/White-Paper-on-Nat-Transport-Policy-1996.pdf (accessed on 25 June 2021).

36. Gwilliam, K. Africa's Transport Infrastructure: Mainstreaming Maintenance and Management. Directions in Development; Infrastructure; World Bank: Washington, DC, USA, 1996.

37. National Research Council. Automotive Fuel Economy: How Far Can We Go? National Academies Press: Washington, DC, USA, 2011.

38. Runji, J. Africa Transport Policies Performance Review: The Need for More Robust Transport Policies; World Bank: Washington, DC, USA, 1992.

39. Export-Import Bank of India. Connecting Africa: Role of Transport Infrastructure. Working paper no.72. Export-import Bank of India. 2018. Available online: https:/ / www.tralac.org/images/docs/12896/connecting-africa-role-of-transport-infrastructureexim-bank-working-paper-march-2018.pdf (accessed on 20 June 2021).

40. United Nations. Economic Commission for Africa. Urbanization and Industrialization for Africa's Transformation: Opportunities and Policy Priorities. 2015. Available online: https:/ / hdl.handle.net/10855/23996 (accessed on 18 June 2021).

41. Saunders, M.; Lewis, P.; Thornhill, A. Research Methods for Business Students, 7th ed.; Pearson Education Limited: London, UK, 2016. 